\title{
Will the London Zoo survive (and how)?
}

The London Zoo, more formally known as the Zoological Society of London, is in serious trouble. In the annual report for 1980 , published last week, the president of the society, Lord Zuckerman, says that the organization is "up against a brick wall". The evidence of the report leaves little doubt that he is correct. Last year, the society made a loss of $£ 666,000$, more than 13 per cent of its income of just under $£ 5$ million. This, however, is not the end of the tale. The society has made large losses in previous years - $£ 130,000$ in 1979 , for example. The novel but ominous implication of last year's result is that the society's bank balance has been almost emptied, and replaced by a substantial overdraft. And that there are unmistakable signs that the chief source of revenue, the entrance fees paid by visitors to the two zoos, in Regent's Park, London, and at Whipsnade, is no longer an inexhaustible pot of gold. For at least two decades, as charges have been increased, the numbers of visitors to the zoos have been falling. Last year, attendance at Regent's Park fell by 11 per cent. Like many other enterprises in inflation-ridden Britain, the society (which is a charity and not technically a business) is being crippled by continually rising costs and the shortage of cash in the economy to spend on the services it provides.

The society's recipe for survival, outlined in the report for 1980 , is logical enough but almost certainly destined for failure. The zoo, the argument goes, is constituted as a charity which provides public services of several different kinds - pleasure for visitors to the two zoos, educational experience for a great many school students and a substantial amount of scientific research, much of it distinguished and not all of it inspired by the veterinary needs of the animals on display. Last year, the two zoos managed to collect some $£ 60,000$ on account of their overtly educational work, by almost any test a miserly recompense for their educational value not merely in London but in the United Kingdom as a whole. Last year, the cost of research $(£ 780,000)$ exceeded by $£ 322,000$ research grant income. So the society is asking why its value as an educational institution should not be more tangibly recognized by local and central government, and why a substantial part of the cost of its research must continue to be met by those who innocently spend an afternoon looking at exotic animals. On both counts, the zoo has a powerful case.

If the zoo were to go out of business - and if its financial position does not improve, it may have no choice - there would be a great outcry from all kinds of interested parties. Local education authorities would be prominent among those protesting that a great institution should not be allowed to sink without trace. They would be complaining that children in their schools would be deprived of an essential part of their education. The spendthrift among them would no doubt argue that if the London Zoo should be closed, it would be necessary for public funds to pay the cost of carting children to the distant game parks of central Africa. Some might even be able to raise the funds. The zoo's case is that if the local authorities are as certain as seems likely to mourn the disappearance of the London Zoo (and perhaps also of Whipsnade), they should contribute more generously now to help keep both institutions in being. The logic is impeccable. The snag is that local authorities are just now as hard-pressed as the zoo itself. And in the nature of British local government, they are incapable of making discretionary expenditure, however prudent. Voluntarily to shoulder part of the cost of supporting the London zoos would be politically risky, but the same local governments (the Greater London Council and the Inner London Education Authority) would have no qualms in foisting on their ratepayers the much larger cost of salvaging the society's collapse.

The obstacles to the zoo's case for more outside support for its research programme are a little less ominous. The point has already been established that for two years there should be a modest subvention ( $£ 134,000$ last year) from central government funds, while the zoo's laboratories can compete for project grants from public and private sources. The accounts for 1980 (which sensibly charge the cost of research "of direct benefit to animal management" against the income of the public exhibits) nevertheless show that the society had to spend $£ 250,000$ of its inadequate income on research. The principle that a private organization should qualify for a public subvention towards the overhead cost of research is unusual but is not an outrage. If a research programme is worthwhile, there is no reason why it should not qualify for public support as if it were carried out in some publicly owned laboratory. The obvious snag, that private management may mean fickle management, is easily overcome by making sure that all grants are short-term grants. In the zoo's present plight, the Advisory Board on the Research Councils, which unimaginatively cuts the annual research cake in Britain, should be willing to do more to help.

Public support of this kind, however, can only be a stop-gap. The zoo itself must acknowledge that its research institutes cannot prosper if they have to live from hand to mouth, keeping watch on the dwindling queues at the visitors' admission gates. It is now clear that the zoo's laboratories have a modest if distinctive contribution to make to some intriguing problems in animal physiology and veterinary medicine, but that they will never be comprehensive or dominating. In the interests of the laboratories, the zoo should therefore seek a more durable framework for its research. For a year now, there has been talk of a consortium including the zoo, the British Museum (Natural History) - which should simplify its name as well as root out cladistic excesses from its public exhibitions - and the Royal Botanic Gardens at Kew. All three institutions have in common their dual concern for public exhibition and scientific research. The connections between the three research programmes are by themselves, however, probably too tenuous to be a durable bridge. Nor is it likely, in present circumstances, that other British zoos would be willing to regard the London Zoo as a central research service for them all, writing cheques accordingly. The zoo's research enterprise might be better able to make its way in the world by setting itself up as a common service for academic and public research laboratories, for example by setting up well-run breeding colonies of primates. Either (or some other) way, the zoo must quickly work out a plan and set out to make it work. In the process, it may find it prudent to put more distance administratively between the research laboratories and the Zoological Society of London as a whole. There is no evidence that the fellows of the society who go to watch the pandas on Sunday mornings presume to interfere with the research, but these days a show of independence would do no harm.

Much the same would be necessary if the zoo were to succeed in recruiting support from local government to keep its zoological display in good shape. Local government politicians are more convinced than others that money means power, in this case influence over exhibition policy. Lord Zuckerman seems bent on persuading London's local politicians tha they should follow the examples of their peers in Berlin, Rotterdam and elsewhere. Would he and the council of the zoo be prepared to share their present absolute power with those willing to keep the zoo out of the red? This unfamiliar thought is neither unthinkable nor unseemly. In the long run, it would help and not hinder if local governments were prepared to share anxieties about the zoo as well as support for it. Experience elsewhere suggests that the propriety of the display need not be damaged. The implication is that the zoo should evolve into a consortium of three separate charities - a research organization, a scientific society of some importance and a public exhibition. In these hard times, it is too dangerous to let the enterprise stand or fall as a whole. That way, it would be better organized for survival, better able to provide its well-wishers with a sense of belonging to a constituency. After all, many of the society's friends think it wrong that animals should be kept in zoos. 